OPEN ACCESS

Edited by:

Edgardo Donati,

National University of La Plata,

Argentina

Reviewed by:

Deniz Ucar,

Harran University, Turkey

Cetin Kantar,

Çanakkale Onsekiz Mart

University, Turkey

Sandeep Panda,

Süleyman Demirel University, Turkey

${ }^{*}$ Correspondence:

Min Gan

ganmin0803@sina.com

${ }^{\dagger}$ These authors have contributed equally to this work

Specialty section:

This article was submitted to Microbiotechnology, Ecotoxicology and Bioremediation,

a section of the journal

Frontiers in Microbiology

Received: 10 March 2019 Accepted: 20 December 2019

Published: 07 February 2020

Citation:

Liu X, Wu H, Gan M and Qiu G (2020) Pyrite-Based Cr(VI) Reduction

Driven by Chemoautotrophic Acidophilic Bacteria.

Front. Microbiol. 10:3082.

doi: 10.3389/fmicb.2019.03082

\section{Pyrite-Based Cr(VI) Reduction Driven by Chemoautotrophic Acidophilic Bacteria}

\author{
Xinxing Liu', Haiyan Wu', Min Gan* and Guanzhou Qiu
}

Department of Biology, Key Laboratory of Biohydrometallurgy of Ministry of Education, School of Minerals Processing and Bioengineering, Central South University, Changsha, China

$\mathrm{Cr}(\mathrm{VI})$ is considered as a priority pollutant, and its remediation has attracted increasing attention in the environmental area. In this study, the driving of pyrite-based $\mathrm{Cr}(\mathrm{VI})$ reduction by Acidithiobacillus ferrooxidans was systematically investigated. The results showed that pyrite-based $\mathrm{Cr}(\mathrm{VI})$ reduction was a highly proton-dependent process and that $\mathrm{pH}$ influenced the biological activity. The passivation effect became more significant with an increase in $\mathrm{pH}$, and there was a decrease in $\mathrm{Cr}(\mathrm{VI})$ reduction efficiency. However, $\mathrm{Cr}(\mathrm{VI})$ reduction efficiency was enhanced by inoculation with $A$. ferrooxidans. The highest reduction efficiency was achieved in the biological system with a $\mathrm{pH}$ range of 1-1.5. Pyrite dissolution and reactive site regeneration were promoted by $A$. ferrooxidans, which resulted in the enhanced effect in $\mathrm{Cr}(\mathrm{VI})$ reduction. The low linear relevancy between $\mathrm{pH}$ and $\mathrm{Cr}(\mathrm{VI})$ dosage in the biological system indicated a complex interaction between bacteria and pyrite. Secondary iron mineral formation in an unfavorable $\mathrm{pH}$ environment inhibited pyrite dissolution, but the passivation effect was relieved under the activity of $A$. ferrooxidans due to S/Fe oxidization. The balance between $\mathrm{Cr}(\mathrm{VI})$ reduction and biological activity was critical for sustainable $\mathrm{Cr}(\mathrm{VI})$ reduction. Pyrite-based $\mathrm{Cr}(\mathrm{VI})$ remediation driven by chemoautotrophic acidophilic bacteria is shown to be an economical and efficient method of $\mathrm{Cr}(\mathrm{VI})$ reduction.

Keywords: pyrite, $\mathrm{Cr}(\mathrm{VI})$ reduction, Acidithiobacillus ferrooxidans, $\mathrm{pH}$, passivation effect

\section{INTRODUCTION}

Hexavalent chromium $[\mathrm{Cr}(\mathrm{VI})]$ is an important raw material that is widely applied in various industries including in metallurgy, electroplating, and leather tanning. Two forms of $\mathrm{Cr}$ with different oxidation states, $\mathrm{Cr}(\mathrm{VI})$ and $\mathrm{Cr}(\mathrm{III})$, usually exist in the natural environment. $\mathrm{Cr}(\mathrm{VI})$ is also considered a priority pollutant, and its remediation has attracted increasing attention in the environmental area (Jiang et al., 2015). The toxicity of $\operatorname{Cr}(\mathrm{III})$ is far lower than that of $\mathrm{Cr}(\mathrm{VI})$, and it can be easily precipitated as $\mathrm{Cr}(\mathrm{OH})_{3}$, while $\mathrm{Cr}(\mathrm{VI})$ is soluble over a wide $\mathrm{pH}$ range. Reduction represents an efficient strategy for $\mathrm{Cr}(\mathrm{VI})$ remediation (Parker et al., 2011; Huggins et al., 2016).

The potential of sulfide minerals such as pyrite or reduced sulfur in redox-sensitive contaminant remediation has attracted great interest in recent years (He and Traina, 2005). However, the pyrite surface is usually passivated due to the formation of $\mathrm{Fe}-\mathrm{Cr}$ compounds, resulting pyrite 
utilization being blocked and thus inhibiting further $\mathrm{Cr}(\mathrm{VI})$ reduction (He and Traina, 2005; Gong et al., 2017). Strengthening measures that have been applied in pyrite or iron-containing material-based $\mathrm{Cr}(\mathrm{VI})$ reduction mainly focus on thermal modification, mechanical crushing, and organic acid/chelating agent addition, etc. (Doyle et al., 2004). Physical treatment increases the specific surface area and degree of pyrite reaction, which enhances $\mathrm{Cr}(\mathrm{VI})$ reduction efficiency. Organic acid and chelating agents act as buffers in the reaction, contributing to the maintenance of a suitable $\mathrm{pH}$ range (Kantar et al., 2015; Kantar and Bulbul, 2016; Mandal et al., 2017). The pyrite surface is property modified after these treatments, and the passivation is also relieved to some extent. However, $\operatorname{Cr}(\mathrm{VI})$ reduction still remains at an unsatisfactory level, as only the pyrite surface is involved in the reduction reaction. Fast and orderly mineral dissolution determines whether pyrite-based $\mathrm{Cr}(\mathrm{VI})$ reduction can be utilized at an industrial scale. According to our previous research, the activity of Acidithiobacillus ferrooxidans significantly enhanced sulfur oxidization and pyrite dissolution as well as the corresponding $\mathrm{Cr}(\mathrm{VI})$ reduction (Gan et al., 2018; Wang et al., 2019).

It should be noted that the influence of $\mathrm{pH}$ on pyrite-based $\mathrm{Cr}(\mathrm{VI})$ reduction remains unclear, especially in the complex system where A. ferrooxidans is present. The chemical equilibrium and the oxidative properties of $\mathrm{Cr}, \mathrm{Fe}$, and $\mathrm{S}$ in solution are mainly determined by protons (Kim et al., 2002; Bae and Hanna, 2015). Protonation/deprotonation, pyrite dissolution, and $\mathrm{Cr}(\mathrm{VI})$ adsorption in the $\mathrm{Cr}(\mathrm{VI})$ reduction reaction are influenced by $\mathrm{pH}$. The surface properties of the pyrite will change with $\mathrm{pH}$ variation. In addition, biological activities, including $\mathrm{Fe} / \mathrm{S}$ metabolism, bacteria proliferation, and physiological activity, are also affected by $\mathrm{pH}$. A higher $\mathrm{Cr}(\mathrm{VI})$ reduction efficiency can be obtained in the optimal $\mathrm{pH}$ range in practical applications. The purposes of this study are to analyze the synergistic effect between acidophilic bacteria and pyrite in $\mathrm{Cr}(\mathrm{VI})$ reduction, to shed light on the effect of $\mathrm{pH}$ and dosage on pyrite-bacteria-Cr(VI) interaction, and to contribute to an increase in pyrite dissolution and $\mathrm{Cr}(\mathrm{VI})$ reduction efficiency. This research is of environmental and practical significance to solve redox-sensitive pollution problems in the mining and smelting industries.

\section{MATERIALS AND METHODS}

\section{Microorganism, Medium, and Culture Conditions}

The acidophilic bacterium A. ferrooxidans 23,270 used in this study was kept at the Key Laboratory of Biometallurgy of Ministry of Education, China. It was cultured in $9 \mathrm{~K}$ medium with the addition of $10 \mathrm{~g} / \mathrm{L} \mathrm{S}$ as an energy source at $30^{\circ} \mathrm{C}$ and at $180 \mathrm{rpm}$. Sublimed sulfur with a purity higher than 99.5\% was purchased from TianJing Hengxing Chemical Reagent Co. Ltd. The composition of the $9 \mathrm{~K}$ medium was as follows: $\left(\mathrm{NH}_{4}\right)_{2} \mathrm{SO}_{4} 3.0 \mathrm{~g} / \mathrm{L}, \quad \mathrm{KCl} 0.1 \mathrm{~g} / \mathrm{L}, \mathrm{K}_{2} \mathrm{HPO}_{4} 0.5 \mathrm{~g} / \mathrm{L}, \mathrm{MgSO}_{4}$ $0.5 \mathrm{~g} / \mathrm{L}$, and $\mathrm{Ca}\left(\mathrm{NO}_{3}\right)_{2} 0.01 \mathrm{~g} / \mathrm{L}$. The medium was adjusted to $\mathrm{pH} 2.0$ with dilute sulfuric acid and autoclaved for $20 \mathrm{~min}$ at $121^{\circ} \mathrm{C}$. All reagents were of analytical grade. Bacteria were harvested at the end of the exponential phase (about 4 days). Cultures were first filtered by $0.45 \mu \mathrm{m}$ filter paper to remove the precipitate. The filtrate was then centrifuged at $12,000 \mathrm{rpm}$ for $20 \mathrm{~min}$ to harvest the cells. Cells were washed twice and resuspended in distilled water.

\section{Cr(VI) Reduction Experiment}

The experiment on the influence of $\mathrm{pH}$ on $\mathrm{Cr}(\mathrm{VI})$ reduction was conducted in a 500-ml conical flask with $75 \mathrm{ml} 9 \mathrm{~K}$ medium and $2 \mathrm{~g}$ pyrite. Natural pyrite was purchased from the geological museum of Guangxi Province, China; this contained $47.3 \% \mathrm{Fe}$ and $48.4 \% \mathrm{~S}$ (wt\%). In the $\mathrm{pH}$-influence experiment, $\mathrm{Cr}(\mathrm{VI})$ was added daily (potassium chromate, 1,000 mg/L) depending on the reductive substance in the reaction solution, which was determined by diphenylcarbazide (DPCI) chromogenic reaction. If the reductive substance was fully consumed, no further $\mathrm{Cr}(\mathrm{VI})$ solution was added. Diphenylcarbazide chromogenic reaction was used to judge whether $\mathrm{Cr}(\mathrm{VI})$ was completely reduced to $\mathrm{Cr}(\mathrm{III})$. The diphenylcarbazide reaction system would turn to purple if the reductive substance was fully consumed by $\mathrm{Cr}(\mathrm{VI})$. The experiment was divided into four groups, namely the $\mathrm{pH}$-stable biological group (BS), the $\mathrm{pH}$-stable chemical group (CS), the $\mathrm{pH}$-independent biological group (BI), and the $\mathrm{pH}$-independent chemical group $(\mathrm{CI})$. The $\mathrm{pH}$ of independent systems was only adjusted in the initial stage, while the $\mathrm{pH}$ of stable systems was adjusted with $5 \% \mathrm{H}_{2} \mathrm{SO}_{4}(\mathrm{v} / \mathrm{v})$ every 2 days. In the $\mathrm{pH}$-independent systems, $\mathrm{pH}$ was set at $0.5,1.0,1.5,2.0,2.5,3.0$, and 3.5 . In the $\mathrm{pH}$-stable systems, $\mathrm{pH}$ was set in the ranges $1-1.5,1.5-2$, $2-2.5,2.5-3$, and 3-3.5. A. ferrooxidans was inoculated into the system with initial cell density at $1 \times 10^{8} / \mathrm{ml}$, which was determined by the microscopic count method. $\mathrm{Cr}(\mathrm{VI})$ solution was added from the second day in both biological and chemical treatments in order to enhance the adaptability of A. ferrooxidans.

In the experiment on the influence of $\mathrm{Cr}(\mathrm{VI})$ dosage, $\mathrm{Cr}(\mathrm{VI})$ solution was added to the system in gradients of $0.5,2,4,6$, and $8 \mathrm{mg}$ per day (potassium chromate, $1,000 \mathrm{mg} / \mathrm{L}$ ). In the dosage-dependent experiment (D), $\mathrm{Cr}(\mathrm{VI})$ was continually added to the conical flask until all of the reductive substance was consumed every day, using the same addition method as in the $\mathrm{pH}$ influence experiment. The reaction was transferred to a bigger conical flask if the reaction volume exceeded $2 / 3$ of the container volume. All of the experiments above were carried out in duplicate.

\section{Physicochemical Parameters of the Reduction Determination}

A pH meter (PHS-3C) with a Pt electrode using a calomel electrode as a reference was employed to measure the $\mathrm{pH}$ and redox potential of the reduction system. The concentration of $\mathrm{Fe}(\mathrm{II})$ and total iron in solutions was determined by using a modified 1, 10-phenanthroline method (Harvey et al., 1955). $\mathrm{Cr}(\mathrm{VI})$ concentration was detected by the 1,5-diphenyl-carbazide method after centrifuging the supernatant for $5 \mathrm{~min}$ at $12,000 \mathrm{rpm}$. Morphological analysis was conducted using an FEI Electron Optics field emission scanning electron microscope 
(Nova NanoSEM230) operated at $15 \mathrm{kV}$ accelerating voltage. Samples were coated with a thin layer of gold in a Pelco Model 3 Sputter 91,000 coater. The precipitate used for XPS analysis were taken at the end of the reaction. First, they were quickly washed with $\mathrm{pH} 2.09 \mathrm{~K}$ medium, and they then underwent freeze vacuum drying for $24 \mathrm{~h}$. X-ray photoelectron spectroscopy analysis was conducted with a Thermo Fisher X-ray photoelectron spectrometer (model ESCALAB 250Xi). Spectra were recorded at a constant pass energy of $20 \mathrm{eV}$ and $0.1 \mathrm{eV} /$ step using an $\mathrm{Al} \mathrm{Ka} \mathrm{X}$-ray source. Binding energies were relative to the $\mathrm{C} 1 \mathrm{~s}$ level at $284.8 \mathrm{eV}$. The spectra of $\mathrm{S}(2 \mathrm{p})$ and $\mathrm{Fe}(2 \mathrm{p})$ were used to investigate the oxidation states and species. The spin-orbit doublets $\mathrm{S} 2 \mathrm{p}_{3 / 2}-\mathrm{S} 2 \mathrm{p}_{1 / 2}$ showed a splitting energy of $1.19 \mathrm{eV}$. The peaks were resolved using CasaXPS version 2.3.18 assuming that the two components had equal peak widths and relative peak areas of $2: 1$.

\section{RESULTS AND DISCUSSION}

\section{Pyrite Dissolution in the Proton Compensation System}

According to the stoichiometry, $\mathrm{Cr}(\mathrm{VI})$ reduction is a proton consumption reaction. A total of $7 \mathrm{~mol} \mathrm{H}^{+}$is consumed in 1 mol $\mathrm{Cr}(\mathrm{VI})$ reduction when $\mathrm{Fe}(\mathrm{II})$ serves as the reductant (Eq. 1), and $4.8 \mathrm{~mol} \mathrm{H}^{+}$is required in $\mathrm{FeS}_{2}$-based $\mathrm{Cr}(\mathrm{VI})$ reduction (Eq. 2; Kim et al., 2001; Lin and Huang, 2008). It can be speculated that $\mathrm{Cr}(\mathrm{VI})$ reduction performance is highly correlated with $\mathrm{pH}$ variation. Pyrite dissolution was mainly caused by two factors, Fe(III)/Cr(VI)-dominated chemical oxidation and $A$. ferrooxidans-mediated biological oxidation (Demoisson et al., 2005, 2007; Lara et al., 2015). The Fe species was an indicator for pyrite dissolution and also the key reductant for $\mathrm{Cr}(\mathrm{VI})$ reduction. The $\mathrm{Fe}(\mathrm{II})$ concentration initially exceeded $600 \mathrm{mg} / \mathrm{L}$ in $\mathrm{pH} 1.0$ and 1.5 in the CI system, while it decreased to ca. $350 \mathrm{mg} / \mathrm{L}$ initially at an $\mathrm{pH}$ of 0.5 (Figure 1). With continuous $\mathrm{Cr}(\mathrm{VI})$ dosing, the $\mathrm{Fe}(\mathrm{II})$ concentration decreased drastically and approached equilibrium after 10 days, indicating that pyrite dissolution and $\mathrm{Fe}(\mathrm{II})$ regeneration were inhibited under high $\mathrm{pH}$. In the chemical system, proton dependent $\mathrm{Fe}(\mathrm{III})$ or $\mathrm{Cr}(\mathrm{VI})$ chemical attack led to pyrite dissolution. It can be identified from Figure 1 that the Fe(II) concentration in the BI system was lower than that in the CI system, which was caused by the biological oxidization of $\mathrm{Fe}$ (II) by $A$. ferrooxidans (Zhu et al., 2013; Christel et al., 2018). This would have adverse effects on $\mathrm{Fe}(\mathrm{II})$-based $\mathrm{Cr}(\mathrm{VI})$ reduction, but it might promote pyrite dissolution. In the BS system, the $\mathrm{Fe}(\mathrm{II})$ concentration remained at $80 \mathrm{mg} / \mathrm{L}$ in the middle and later periods, significantly higher than that in the CI system, which indicated that proton compensation promoted pyrite dissolution. According to previous research, $\mathrm{Cr}(\mathrm{VI})$ reduced to $\mathrm{Cr}(\mathrm{III})$ in two ways: intermediate sulfur and $\mathrm{Fe}(\mathrm{II})$ released from pyrite dissolution and active sites on pyrite (Quilntana et al., 2001; Bae and Hanna, 2015; Li et al., 2016). Therefore, both reduction pathways should be taken into account in practical applications to enhance the reduction efficiency.

$$
\begin{gathered}
6 \mathrm{Fe}_{(a q)}^{2+}+\mathrm{Cr}_{2} \mathrm{O}_{7(a q)}^{2-}+14 \mathrm{H}_{(a q)}^{+} \rightarrow 6 \mathrm{Fe}_{(a q)}^{3+}+2 \mathrm{Cr}_{(a q)}^{3+}+7 \mathrm{H}_{2} \mathrm{O} \\
3 \mathrm{FeS}_{2}+15 \mathrm{HCrO}_{4}^{-}+57 \mathrm{H}^{+} \stackrel{\text { A.f }}{\rightarrow} 3 \mathrm{Fe}^{3+}+6 \mathrm{SO}_{4}^{2-}+15 \mathrm{Cr}^{3+}+36 \mathrm{H}_{2} \mathrm{O}(2) \\
\mathrm{E}=E^{0}+\frac{n \mathrm{~F}}{R T} \ln \left(\mathrm{Fe}^{3+} / \mathrm{Fe}^{2+}\right) \\
\mathrm{FeS}_{2}+8 \mathrm{H}_{2} \mathrm{O}+14 \mathrm{Fe}^{3+} \rightarrow 15 \mathrm{Fe}^{2+}+2 \mathrm{SO}_{4}^{2-}+16 \mathrm{H}^{+}
\end{gathered}
$$

Comparing $\mathrm{Fe}(\mathrm{II})$ (Figure 1) and $\mathrm{TFe}$ (Figure 2) in the systems, it can be found that Fe mainly existed in the form of $\mathrm{Fe}(\mathrm{II})$. TFe in the CI pH 0.5 system was higher than $400 \mathrm{mg} / \mathrm{L}$ during the whole reduction. The high $\mathrm{Fe}(\mathrm{III})$ concentration contributed to a high redox potential (Eq. 3) and promoted pyrite oxidation dissolution (Eq. 4). Fe decreased rapidly with an increase in $\mathrm{pH}$ and may have been precipitated in secondary iron minerals such as jarosite (Zhu et al., 2013; Gan et al., 2015). The deposition of secondary iron minerals on the pyrite surface would have been unfavorable for pyrite dissolution (Stott et al., 2000; He and Traina, 2005). Basically, the TFe concentration in the biological system was lower than that in both the $\mathrm{pH}$-independent and -stable chemical treatments. This indicated that more passivation substances formed under the activity of A. ferrooxidans. TFe in the $\mathrm{pH}$-stable system decreased in the initial stage and entered into a stable phase after 20 days and was significantly higher than that in $\mathrm{pH}$-independent group. A stable and low $\mathrm{pH}$ promoted pyrite decomposition.

As analyzed above, $\mathrm{Cr}(\mathrm{VI})$ reduction was a proton-consumption reaction, while protons can be regenerated in the pyrite biological oxidization process. Moreover, the $\mathrm{pH}$ of the system is maintained in a specific interval under exogenetic proton compensation. Hence, $\mathrm{pH}$ variation was a comprehensive reflection of $\mathrm{Cr}(\mathrm{VI})$ reduction, biological oxdization, and proton compensation. It showed that the $\mathrm{pH}$ of proton compensation systems was kept in a stable interval (Figures $\mathbf{3 A}, \mathbf{C}$ ). The $\mathrm{pH}$ of the CS system was maintained basically at $0.8,1.4,2.0,2.9,3.4$, and 4.4 , and $\mathrm{pH}$ of the corresponding biological system was $0.8,1.2,1.6$, $2.5,3.0$, and 3.3 because of the protons generated in sulfur oxidation by $A$. ferrooxidans. This phenomenon also manifested the dissolution effect of $A$. ferrooxidans on pyrite (Eq. 5). When A. ferrooxidans induced $1 \mathrm{~mol} \mathrm{FeS}_{2}$ dissolution, 1 mol $\mathrm{Fe}(\mathrm{II})$ and $2 \mathrm{~mol} \mathrm{H}^{+}$would be produced, resulting in the regeneration of proton and reactive sites as well as sustainable $\mathrm{Cr}(\mathrm{VI})$ reduction (Tu et al., 2017). An obvious rise in $\mathrm{pH}$ could be observed in the $\mathrm{CI}$ and BI systems (Figures 3B,D). It reached 1.0, 2.8, 2.9, $3.1,4.5,4.5$, and 4.6 at the endpoint in CI systems, but the corresponding $\mathrm{pH}$ in $\mathrm{BI}$ systems was $1.5,2.7,2.8,3.0,3.0,3.1$, and 3.1 respectively. This indicated the effective pyrite dissolution and proton regeneration under the activity of $A$. ferrooxidans, which was critical for $\mathrm{Cr}(\mathrm{VI})$ reduction.

$$
2 \mathrm{FeS}_{2}+2 \mathrm{H}_{2} \mathrm{O}+7 \mathrm{O}_{2} \stackrel{\text { A.f }}{\rightarrow} 2 \mathrm{Fe}^{2+}+4 \mathrm{SO}_{4}^{2-}+4 \mathrm{H}^{+}
$$

The redox potential was a comprehensive reflection of a series biogeochemical processes including pyrite dissolution, $\mathrm{Fe}(\mathrm{II})$ 

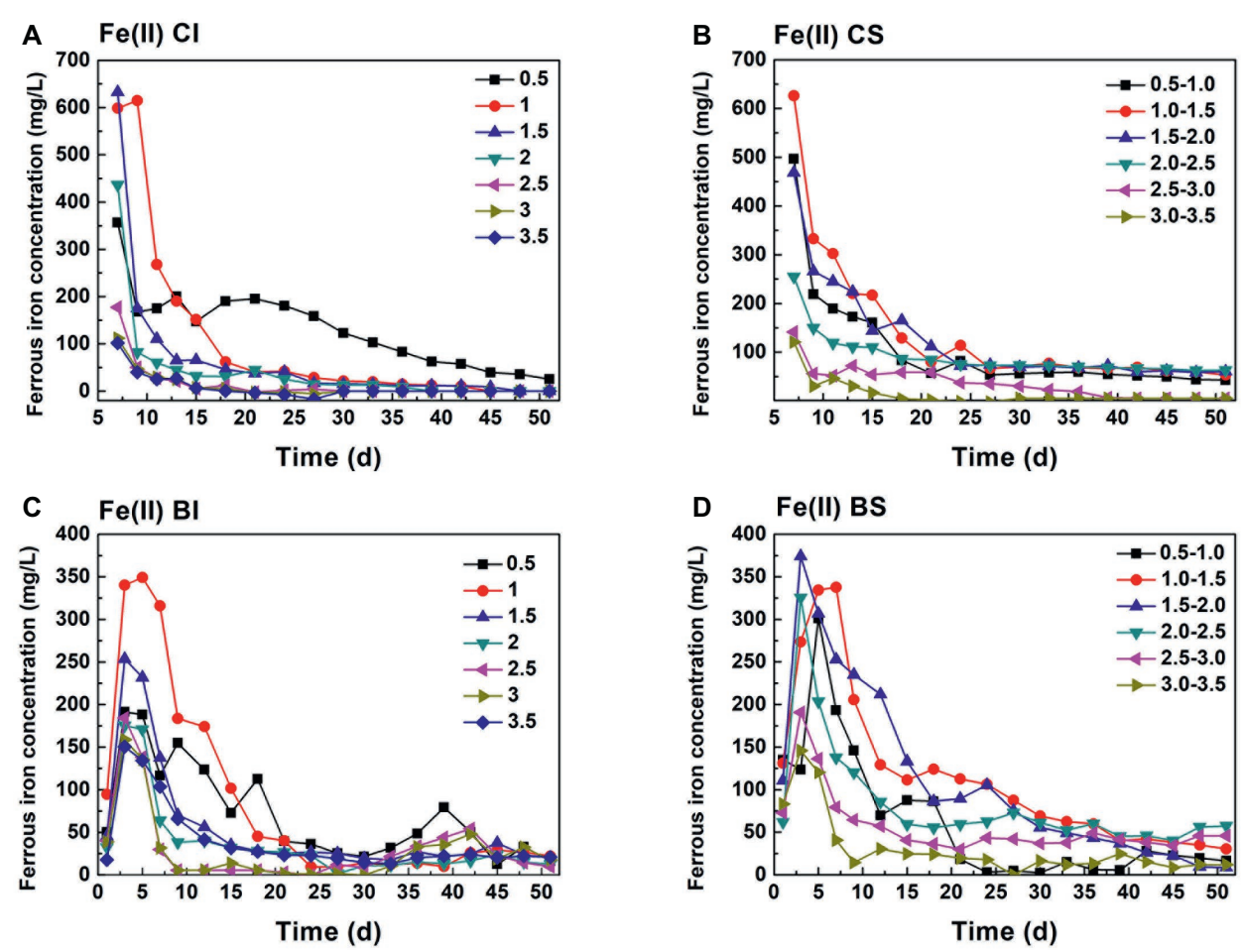

FIGURE 1 | Variation of ferrous iron in pH-stable and pH-independent system; (A, Cl): pH-independent chemical group, (B, CS): pH-stable chemical group, (C, BI): pH-independent biological group, (D, BS): pH-stable biological group.
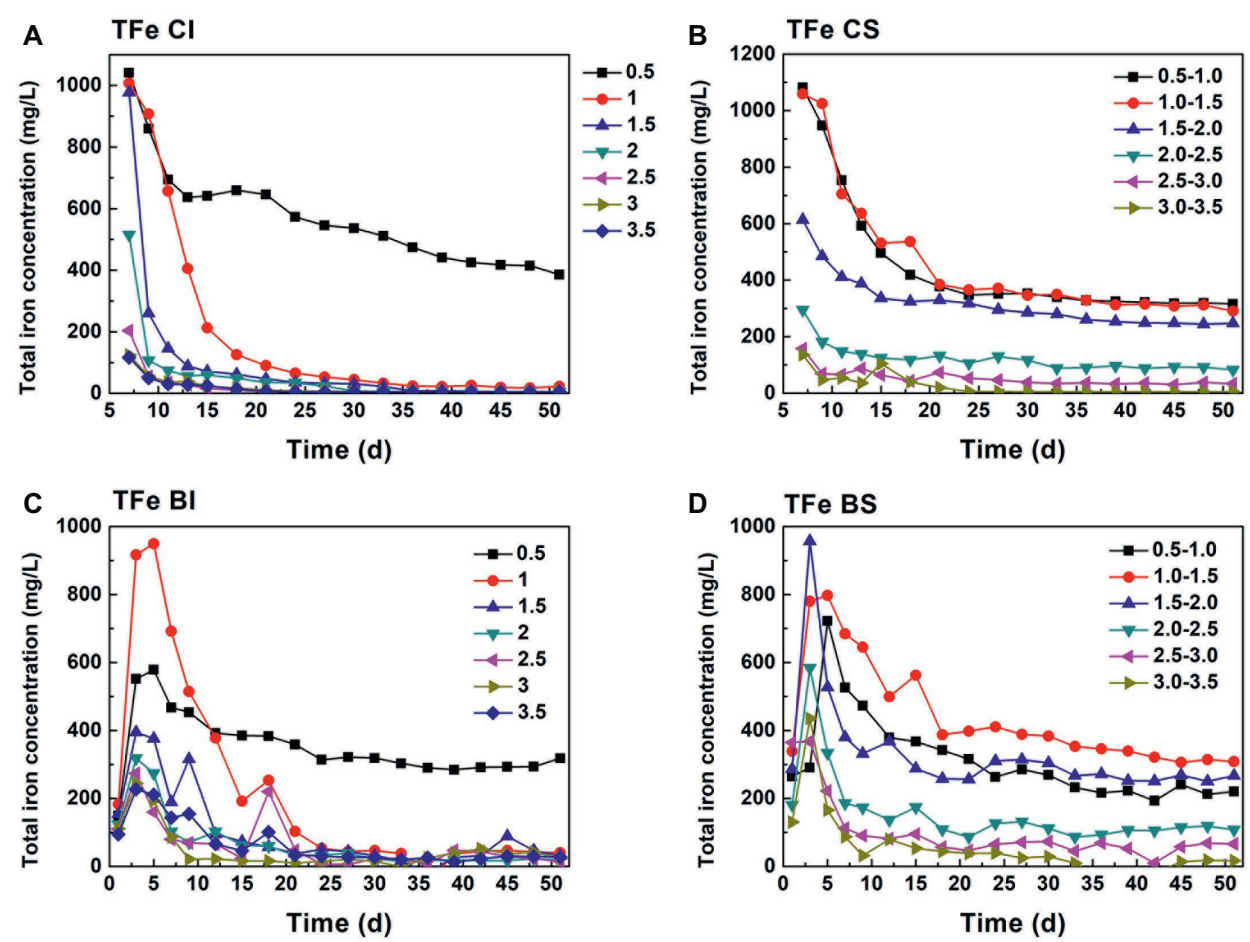

FIGURE 2 | Total iron change in pH-stable and pH-independent system; (A, Cl): pH-independent chemical group, (B, CS): pH-stable chemical group, (C, BI): $\mathrm{pH}$-independent biological group, (D, BS): $\mathrm{pH}$-stable biological group. 

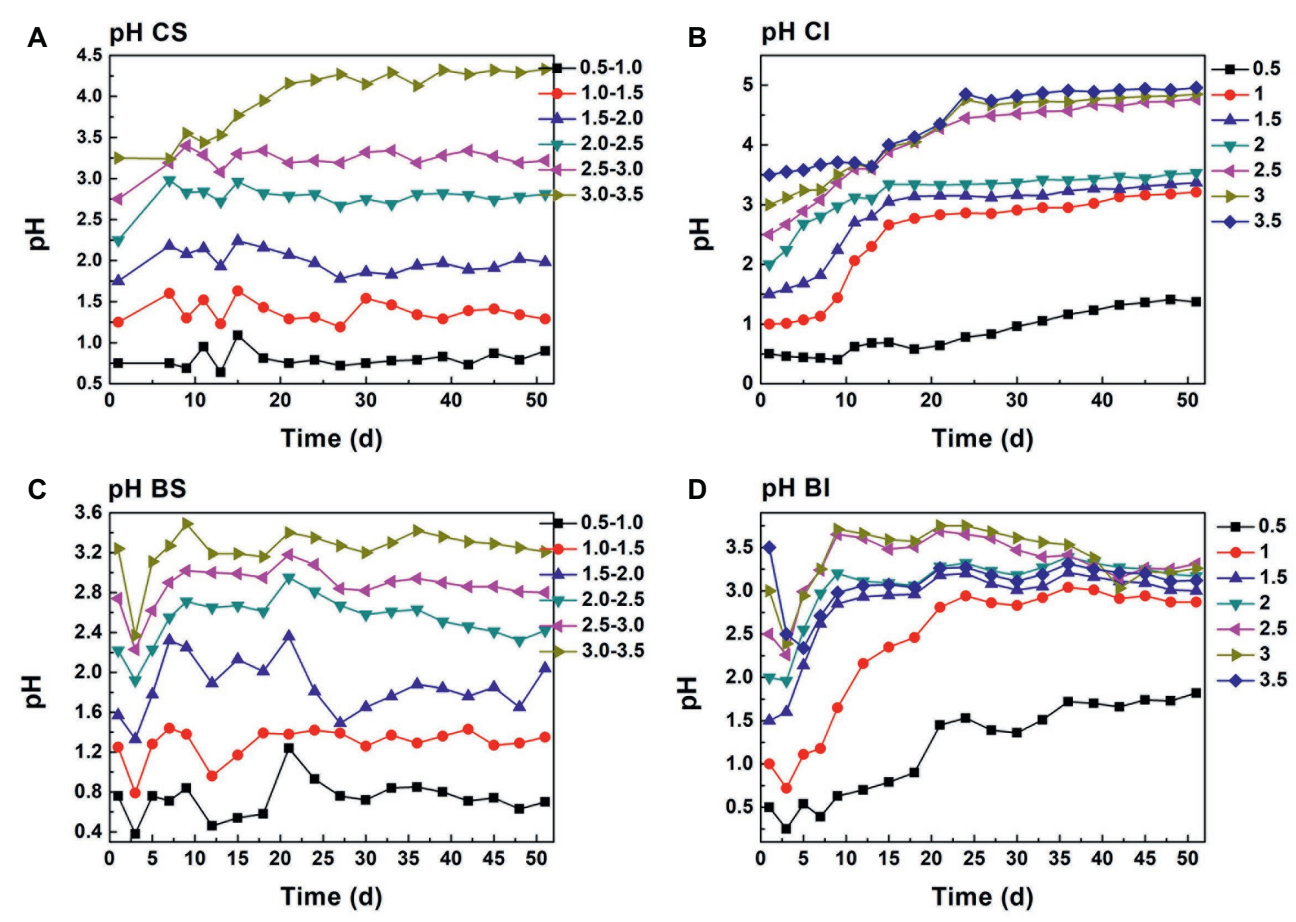

FIGURE 3 I pH change in proton compensation and un-compensation system; (A, CS): pH-stable chemical group, (B, Cl): pH-independent chemical group, (C, BS): pH-stable biological group, (D, BI): pH-independent biological group.

oxidization, and secondary iron mineral formation (Sun et al., 2015). The redox potential was maintained at around $420 \mathrm{mV}$ in the initial pH $0.5 \mathrm{CI}$ system, and it decreased to $300 \mathrm{mV}$ in the initial pH 3.5 system (Supplementary Figure S1). Redox potential decreased as $\mathrm{pH}$ increased with no proton compensation, and this occurred in both biological and chemical systems. The protons produced by acidophilic bacteria in pyrite dissolution and sulfur oxidization cannot replenish the protons consumed by $\mathrm{Cr}(\mathrm{VI})$ reduction. Redox potential in $\mathrm{pH}$-stable treatment was obviously higher than that with $\mathrm{pH}$-independent treatment. Redox potential in the CS $\mathrm{pH} 0.5-1.0$ system reached $480 \mathrm{mV}$, and it decreased to $320 \mathrm{mV}$ with an increase in $\mathrm{pH}$. Fe(III) and protons will have attacked pyrite directly and promoted pyrite dissolution.

\section{Cr(VI) Reduction Behavior}

$\mathrm{Cr}(\mathrm{VI})$ reduction in the $\mathrm{CI}$ system was basically negatively correlated with $\mathrm{pH}$ (Figure 4). The $\mathrm{Cr}(\mathrm{VI})$ reduction dosage increased steadily in $\mathrm{pH} 0.5$ and 1.0 (CI and BI system) during the first 12 days. The reduction dosage in $\mathrm{pH} 0.5$ was higher than $8 \mathrm{mg}$ each day during the whole reaction. However, an obvious decrease in the $\mathrm{Cr}(\mathrm{VI})$ dosage could be observed when the initial $\mathrm{pH}$ was higher than 1.0, which was consistent with the low $\mathrm{Fe}$ (II) concentration and high $\mathrm{Fe}(\mathrm{III})$ precipitation ratio. Sustainable $\mathrm{Cr}(\mathrm{VI})$ reduction was only achieved in the $\mathrm{pH} 0.5$ system without exogenetic proton compensation. In addition, it should be noted that the daily reduction dosage increased when inoculated with $A$. ferrooxidans, and the plateau stage was postponed. Figure 1 shows that the $\mathrm{Fe}(\mathrm{II})$ concentration in the biological system was lower than that in the chemical system.
Based on this fact, it can be speculated that A. ferrooxidans activated the reactive sites on pyrite and led to high reduction efficiency. The pyrite-based $\mathrm{Cr}(\mathrm{VI})$ reduction efficiency was enhanced by $A$. ferrooxidans, and this promotion effect was most obvious in the $\mathrm{pH} 1.0-1.5$ interval, which might relate to the optimal physiological activity of $A$. ferrooxidans under this $\mathrm{pH}$.

Figures 4E,F exhibits the $\mathrm{Cr}(\mathrm{VI})$ reduction capacity in the $\mathrm{pH}$-independent and -stable systems. The reduction capacity of the $\mathrm{BI}$ and $\mathrm{CI}$ systems decreased with increasing $\mathrm{pH}$. The reduction capacity of the biological system was significantly higher than that of the chemical system. This also verified that reactive site regeneration under $A$. ferrooxidans activity resulted in the promotion of $\mathrm{Cr}(\mathrm{VI})$ reduction. The reduction capacity nearly remained unchanged when $\mathrm{pH}$ was higher than 2.0 in the proton uncompensated circumstance. The highest $\mathrm{Cr}(\mathrm{VI})$ reduction levels reached were $932 \mathrm{mg}$ in the chemical system and $1,113 \mathrm{mg}$ in the biological system under a stable $\mathrm{pH}$ in the range 1.0-1.5 (Figures 4E,F). The reduction efficiency of the $\mathrm{pH}$-stable biological system was improved by $4.2,19.4,14.7,72.3,68.1$, and $94.3 \%$ compared with the $\mathrm{pH}$-stable chemical system with $\mathrm{pH}$ increase. The reduction capacity was not fully consistent with free $\mathrm{Fe}$ (II) content in solution, which further confirmed the speculation that reactive sites on pyrite acted as the reductant for $\mathrm{Cr}(\mathrm{VI})$. Figure 5 shows the linear dependence between $\mathrm{pH}$ variation and daily dosage $(\mathrm{A}, \mathrm{C})$ /total dosage $(\mathrm{B}, \mathrm{D})$. As aforementioned, $\mathrm{Cr}(\mathrm{VI})$ reduction was dependent on multiple factors, which led to a low relevancy between $\mathrm{pH}$ and daily dosage. However, a typical linear dependence was exhibited between total dosage and $\mathrm{pH}$. The linear dependency in the CI system was higher than 0.89 , and 

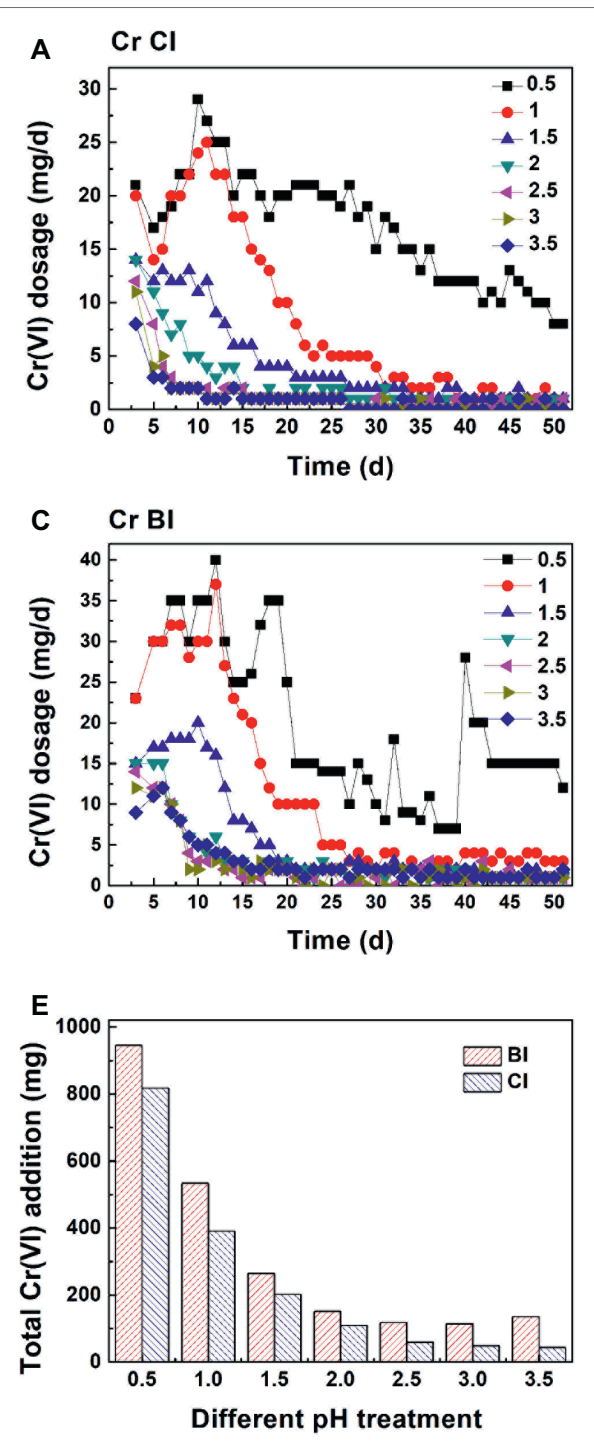
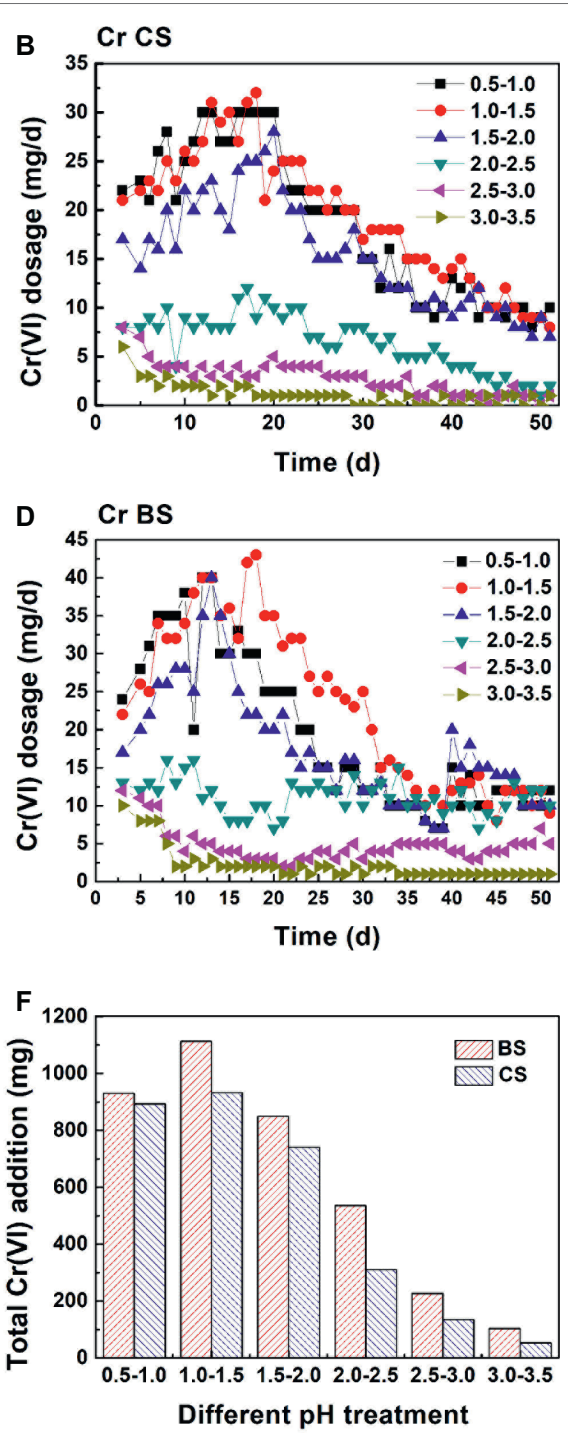

FIGURE 4 | Cr(MI) reduction behavior in different systems: $\mathrm{Cr}(\mathrm{VI})$ daily reduction behavior in the $\mathrm{pH}$-independent chemical group (A, Cl), pH-stable chemical group (B, CS), $\mathrm{pH}$-independent biological group (C, Bl), and pH-stable biological group (D, BS); total amount of $\mathrm{Cr}(\mathrm{VI})$ reduction in the pH-independent (E) and -stable (F) systems.

it decreased prominently in the biological system. The complexity of the reaction increased due to interaction between bacteria and pyrite, which resulted in the decreasing relevancy.

\section{The Relationship Between Reduction Performance and $\mathrm{Cr}(\mathrm{VI})$ Dosage}

Besides proton compensation, $\mathrm{Cr}(\mathrm{VI})$ dosage was further investigated. Figures 6A,B shows the $\mathrm{pH}$ and redox potential change under $\mathrm{Cr}(\mathrm{VI})$ dosage gradients. A steady decrease trend can be observed with $\mathrm{Cr}(\mathrm{VI})$ addition (0.5-8 $\mathrm{mg}$ dosage). The decreasing $\mathrm{pH}$ indicated the dissolution of pyrite. Proton produced by bacteria exceeded those consumed in the reduction reaction. Basically, $\mathrm{pH}$ was maintained at $0.4,0.6,1.0,1.1$, and 1.2 at the plateau (about 37 days) with increasing dosage. In contrast, the $\mathrm{pH}$ of the maximal dosing system (D) increased drastically and reached 3.0 on the $10^{\text {th }}$ day. A. ferrooxidans cannot be adsorbed onto the pyrite surface tightly in the initial reaction stage (Supplementary Figure S2), so biofilm formation was impossible because of the weak interaction between bacteria and pyrite (Mielke et al., 2003; Zhu et al., 2015). If reductive sulfide and $\mathrm{Fe}$ (II) was completely consumed by $\mathrm{Cr}$ (VI), it would lead to energy source scarcity and bacteria proliferation stagnation. The amount of $\mathrm{Cr}(\mathrm{VI})$ dosing in the maximal dosing system (D) was no higher than $4 \mathrm{mg}$ each day after 10 days, which implied that the biological dissolution effect and active site regeneration activity of $A$. ferrooxidans on pyrite was inhibited. Redox potential presented a different variation trend than did $\mathrm{pH}$. Redox potential reached $480 \mathrm{mV}$ in the 4,6 , and $8 \mathrm{mg}$ dosage systems, and that in the 0.5 and $2 \mathrm{mg}$ systems was lower than in the former, being maintained at approximately $440 \mathrm{mV}$. In practical applications, $\mathrm{Cr}(\mathrm{VI})$ dosage is one of the foremost parameters that should be taken into consideration. 

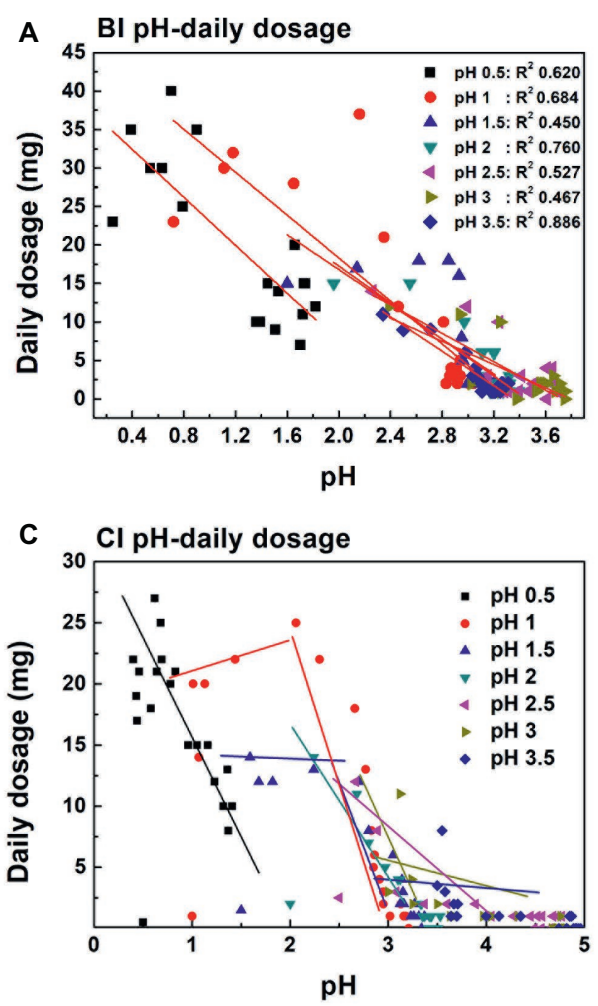

B

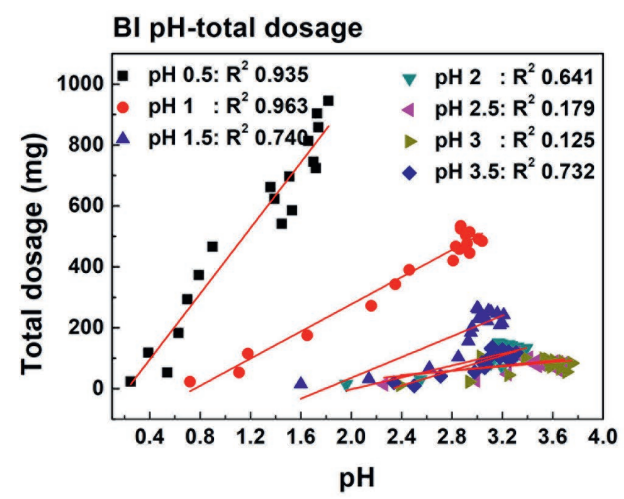

D

(d) $\mathrm{Cl} \mathrm{pH-total} \mathrm{dosage}$

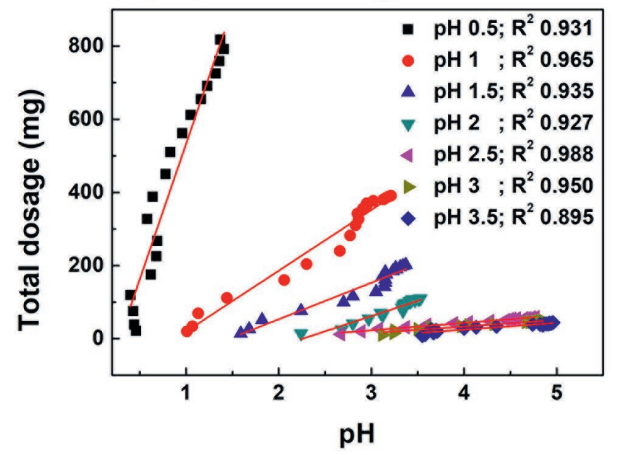

FIGURE 5 | Linear dependence between daily dosage (A,C)/total dosage (B,D) and pH variation in $\mathrm{pH}$ initial adjustment system.
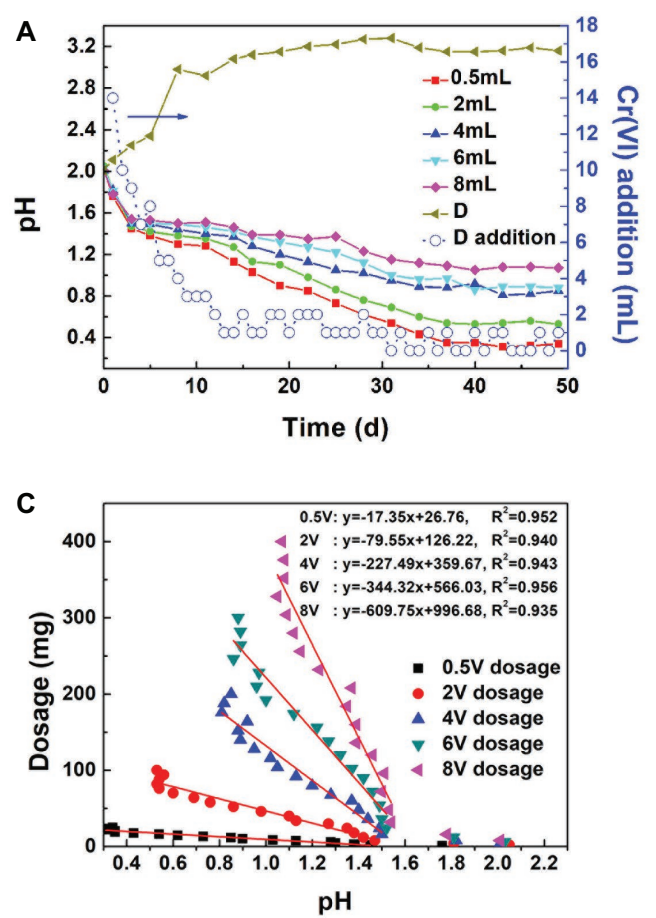
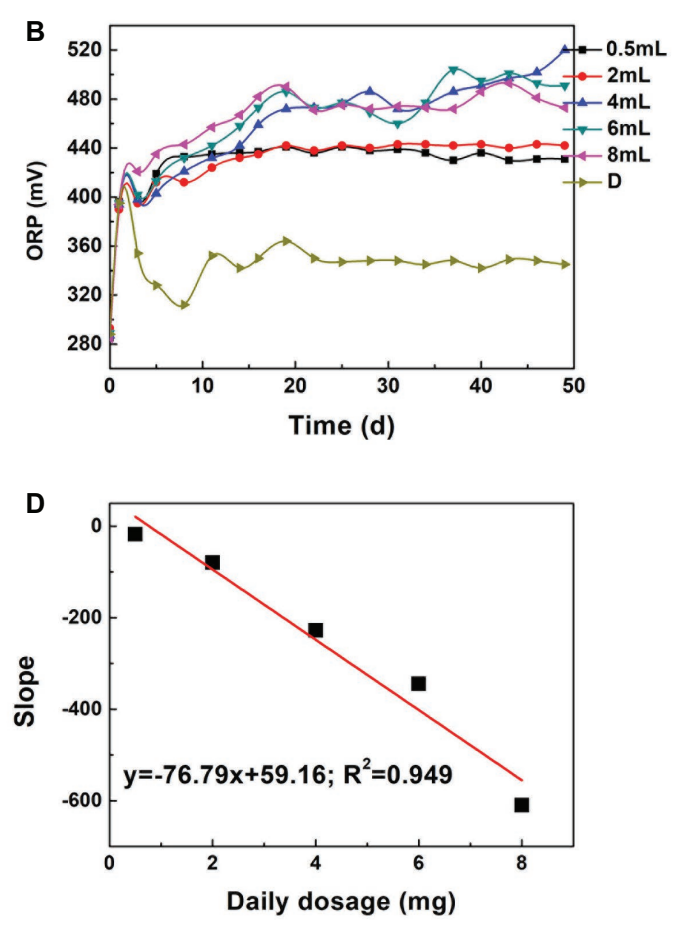

FIGURE 6 | The influence of dosage on $\mathrm{pH}$ (A) and ORP (B), linear dependence between dosage and system $\mathrm{pH}$ (C), linear dependence between slope and daily dosage (D): D means the $\mathrm{pH}$ and ORP variation in the maximal $\mathrm{Cr}(\mathrm{VI})$ dosing system; (D) addition represents Cr(VI) dosing every day. 
The correlation coefficient between $\mathrm{Cr}(\mathrm{VI})$ total dosage and $\mathrm{pH}$ reached $0.952,0.940,0.943,0.956$, and 0.938 , respectively, with increasing dosage (Figures 6C,D). The steady decrease in $\mathrm{pH}$ implied that the proton regeneration effect was stronger than the acid consumed in $\mathrm{Cr}(\mathrm{VI})$ reduction. The absolute values of the $\mathrm{pH}$-dosage slope were 17.35, 79.55, 227.49, 344.32, and 609.75. The slope increased with dosage. The significant positive correlation between proton consumption ratio and daily dosage illustrated that proton consumption increased with daily dosage. A linear model can be applied in $\mathrm{pH}$ prediction to avoid excessive $\mathrm{Cr}(\mathrm{VI})$ addition and reduce toxicity to bacteria.

\section{Pyrite Dissolution and Bacteria Proliferation Under Different Dosages}

$\mathrm{Fe}(\mathrm{II})$ and $\mathrm{TFe}$ are direct indicators of the complex process that includes biologically and chemically induced pyrite dissolution, $\mathrm{Fe}$ (II) oxidation, and iron coprecipitation. Figure 7 shows that $\mathrm{Fe}(\mathrm{II})$ decreased continually, and only $26.6 \mathrm{mg} / \mathrm{L}$ $\mathrm{Fe}$ (II) remained on the 11th day in the D system. In contrast, the $\mathrm{Fe}(\mathrm{II})$ concentration in certain dosage systems increased rapidly in the first 10 days, which implied that Fe(II) regeneration exceeded that consumed in $\mathrm{Cr}(\mathrm{VI})$ reduction and bacteria metabolism. The $\mathrm{SO}_{4}{ }^{2-}$ variation trend was similar to the $\mathrm{Fe}$ (II) change (Figure 7C). The steadily increasing total iron indicated that the formation of secondary iron minerals and the surface passivation effect were not significant. High $\mathrm{Fe}$ (III) iron concentration promoted pyrite dissolution and $\mathrm{Fe}(\mathrm{II})$ regeneration (Eq. 4). A. ferrooxidans proliferated quickly in the first 20 days (Figure 7D), which indicated that the energy source supply was sufficient. In contrast, bacterial proliferation in the maximal dosing system was basically stagnant due to the high-pH environment and lack of available substrate. These phenomena illustrate that the reduction reaction was sustainable when $\mathrm{Cr}(\mathrm{VI})$ reduction and bacteria activity were in a balanced state.

In the maximal dosing system, no bacterial corrosion pits could be found. EDS analysis showed that the $\mathrm{Cr}, \mathrm{Mg}, \mathrm{Si}$, and $\mathrm{P}$ contents reached $3.78,5.48,1.24$, and $1.79 \%$, respectively (Supplementary Table S1). The surface element composition was consistent with the characteristics of a passivation layer (Stott et al., 2000; He and Traina, 2005). This layer led to the inhibition of the reduction reaction. However, corrosion pits spread through the mineral surface in the fixed dosing systems, and intimate interaction occurred between bacteria and pyrite.

\section{Morphology and Phase Transformation in $\mathrm{pH}$-Controlled and pH-Non-controlled Systems}

Figure 8 shows that direct interaction occurred between $A$. ferrooxidans and the mineral. Plentiful cells were attached to the pyrite surface in the BS $\mathrm{pH} \quad 0.5-1.0$ and $1.5-2.0$ systems, especially the latter. Corrosion pits spread on the pyrite surface, and extracellular polymeric substances were secreted outside cells. Research has shown that the optimal $\mathrm{pH}$ for $A$. ferrooxidans is in the 1.5-2.5 range and that the proliferation and biological activity would be inhibited in a high-pH environment (Meruane and Vargas, 2003). Reduction efficiency increased with decreasing $\mathrm{pH}$ in an environment lacking $A$. ferrooxidans, while the highest reduction efficiency of the biological system was achieved in
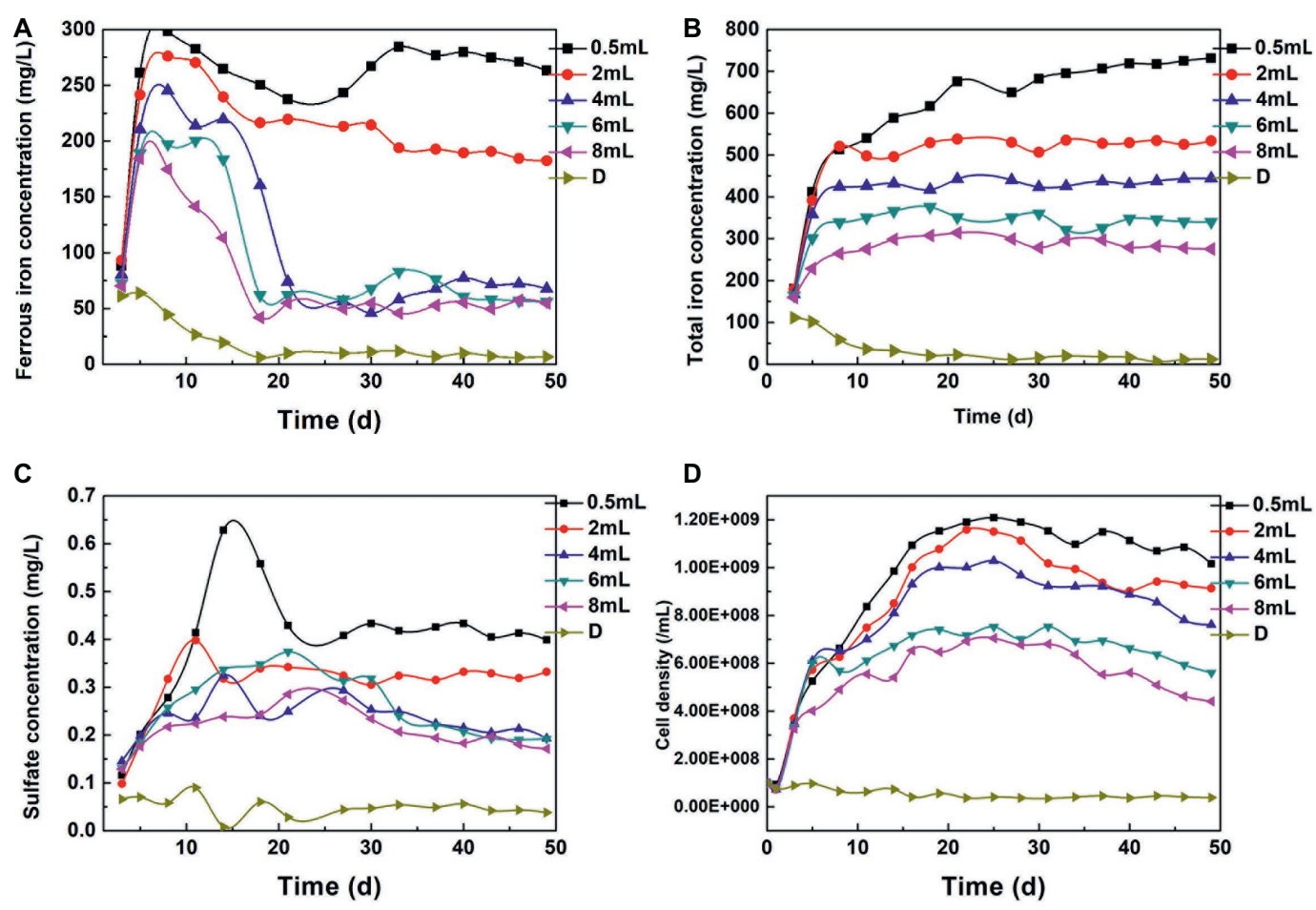

FIGURE 7 | The Change of Fe(II) (A), TFe (B), $\mathrm{SO}_{4}{ }^{2-}$ (C), and bacterial density (D) under different dosage. 

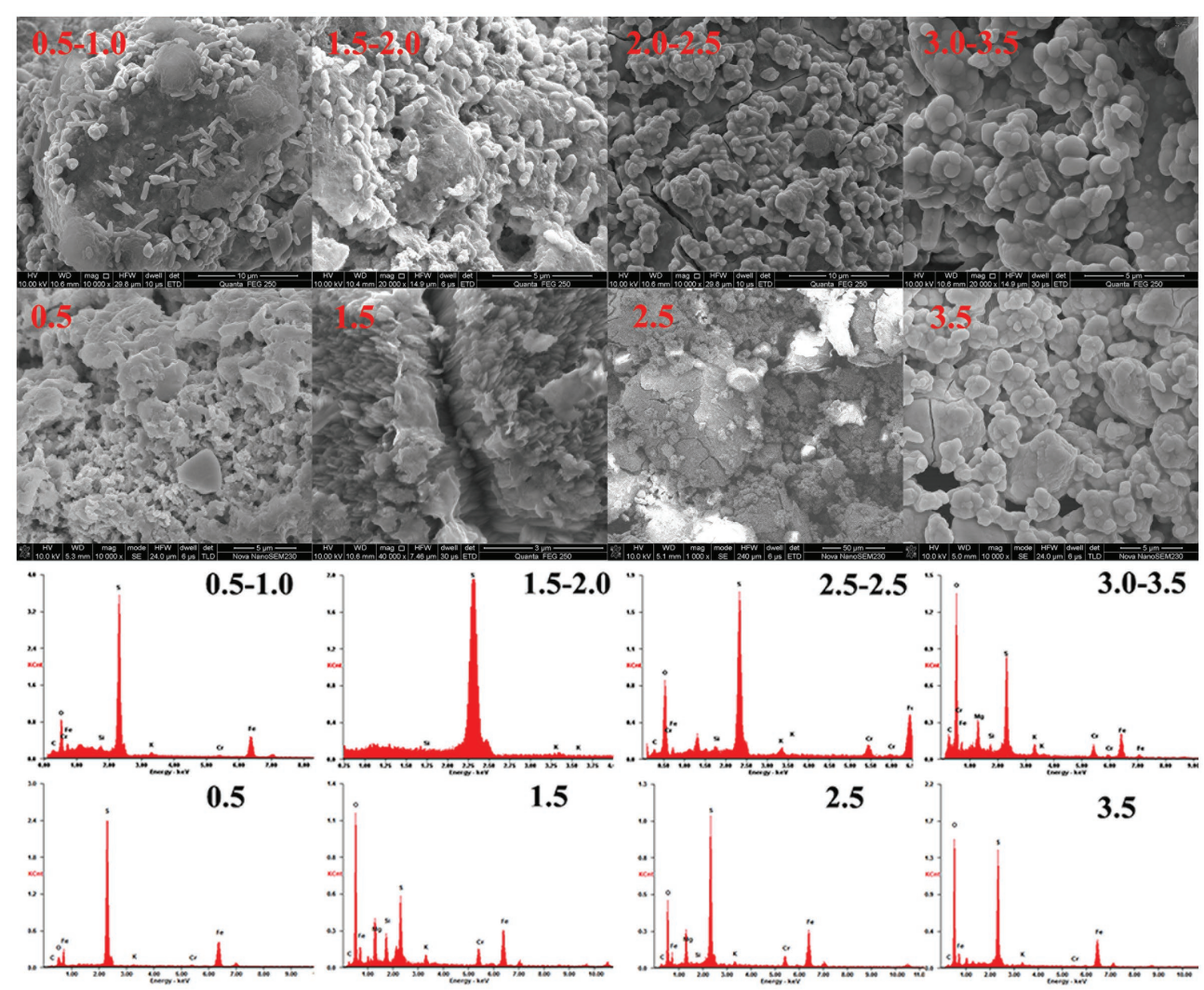

FIGURE 8 | Morphology and EDS spectra of pyrite in an A. ferrooxidans-present system.

a specific $\mathrm{pH}$ interval. A. ferrooxidans in the optimal physiological condition accelerated pyrite dissolution and enhanced the corresponding $\mathrm{Cr}(\mathrm{VI})$ reduction. A balance between $\mathrm{Cr}(\mathrm{VI})$ reduction and biological activity was critical for sustainable reduction. The cell adsorption efficiency decreased markedly when the $\mathrm{pH}$ was higher than 2.0, and a passivation film was also formed under this circumstance. This result was also verified by the EDS results (Supplementary Tables S2, S3). The $\mathrm{Cr}$ content in $\mathrm{BS} \mathrm{pH} 0.5-1.0$ and 1.5-2.0 was 1.33 and $1.09 \%$, respectively, while it increased to 5.32 and $4.03 \%$ under $\mathrm{pH} 2.0-2.5$ and 3.0-3.5 conditions. The $\mathrm{K}$ content also reached 1.95 and $1.92 \%$. The high $\mathrm{K}$ and $\mathrm{Cr}$ contents confirmed that a passivation layer formed on the pyrite (Stott et al., 2000; $\mathrm{He}$ and Traina, 2005; Cordoba et al., 2009). Corrosion pits also existed on the pyrite surface in the BI $\mathrm{pH} 0.5$ and 1.0 systems, but cell-pyrite interaction was not significant. The $\mathrm{Cr}$ content in these four systems was $1.38,4.46,5.8$, and 7.18\%, respectively, with increasing initial $\mathrm{pH}$, much higher than that in the stable system. The interaction between cells and minerals, as well as the passivation film formation, can be regulated through proton compensation.

XRD analysis (Supplementary Figure S3) was used to identify phase transformation in the different reduction systems. The results showed that the main substance was still pyrite, with trace elemental sulfur, under low-pH conditions (BI/CI $\mathrm{pH}$ 0.5, BS/CS 0.5-1.0). As the EDS results showed, there was $39.0 \%$ sulfur content in the BI system and $37.07 \%$ in the BS system, which also confirmed sulfur formation in the reduction process. $\mathrm{Fe}(\mathrm{II})$ oxidized and dissolved from the pyrite lattice under the combined effect of $\mathrm{Fe}(\mathrm{III}) / \mathrm{Cr}(\mathrm{VI})$ and biological oxidization (Mullet et al., 2007). However, $\mathrm{S}_{2}{ }^{2-}$ was oxidized to elemental sulfur through the thiosulfate pathway. Moreover, sulfur species are inert to abiotic oxidation in acidic environments, so oxidation is exclusively carried out by microorganisms (Schippers et al., 1996; Olson et al., 2003). Elemental sulfur would be accumulated on the bulk mineral if sulfur-oxidizing microorganisms were absent or their activity inhibited. Therefore, A. ferrooxidans-dominant sulfur oxidation determined the transformation of reductive sulfide. In contrast, jarosite, hydroxyl iron sulfate, and chromium-iron compounds were identified from the residue in higher $\mathrm{pH}$ environments (initial $\mathrm{pH}$ system 3.5 and stable $\mathrm{pH}$ system $3.0-3.5$ ). Secondary iron minerals resulted in a passivation effect in higher $\mathrm{pH}$ environments, which was more significant than the coverage with elemental sulfur in low-pH environments. The above results were also verified by the XPS results (Figure 9). Fe species including $\mathrm{Fe}(\mathrm{II})-\mathrm{S}, \mathrm{Fe}(\mathrm{III})-\mathrm{O}$, and $\mathrm{Fe}(\mathrm{II})-\mathrm{O} / \mathrm{Fe}(\mathrm{III})-\mathrm{S}$ existed in both $\mathrm{pH}$ environments ( $\mathrm{Gan}$ et al., 2015; Gong et al., 2017), but there are marked differences between samples. The Fe(II)-S species was the main component of the optimal $\mathrm{pH}$ environment pyrite. This confirmed that reactive sites efficiently regenerated, and the pyrite surface was kept "fresh" 
under this circumstance. However, the $\mathrm{Fe}(\mathrm{II})-\mathrm{S}$ species was extremely scarce in the high-pH systems and was oxidized to high-valence $\mathrm{Fe}(\mathrm{III})$. The main Fe species were $\mathrm{Fe}(\mathrm{III})-\mathrm{O}$ and $\mathrm{Fe}$ (III)-S, which were critical components of the secondary iron minerals. Sulfur intermediate species transformations in different environments were also analyzed. Reduction state $\mathrm{S}_{2}{ }^{2-}$ and $\mathrm{S}^{2-}$, intermediate $\mathrm{S}_{\mathrm{n}}{ }^{2-}$ and $\mathrm{S}^{0}$, and $\mathrm{SO}_{\mathrm{x}}{ }^{2-}\left(\mathrm{SO}_{3}{ }^{2-} / \mathrm{SO}_{4}{ }^{2-}\right)$ existed on the pyrite. It can be noted that the main difference was the concentration of $\mathrm{SO}_{\mathrm{x}}{ }^{2-}$. The $\mathrm{SO}_{3}{ }^{2-} / \mathrm{SO}_{4}{ }^{2-}$ species content at the pyrite surface was obviously higher in high-pH
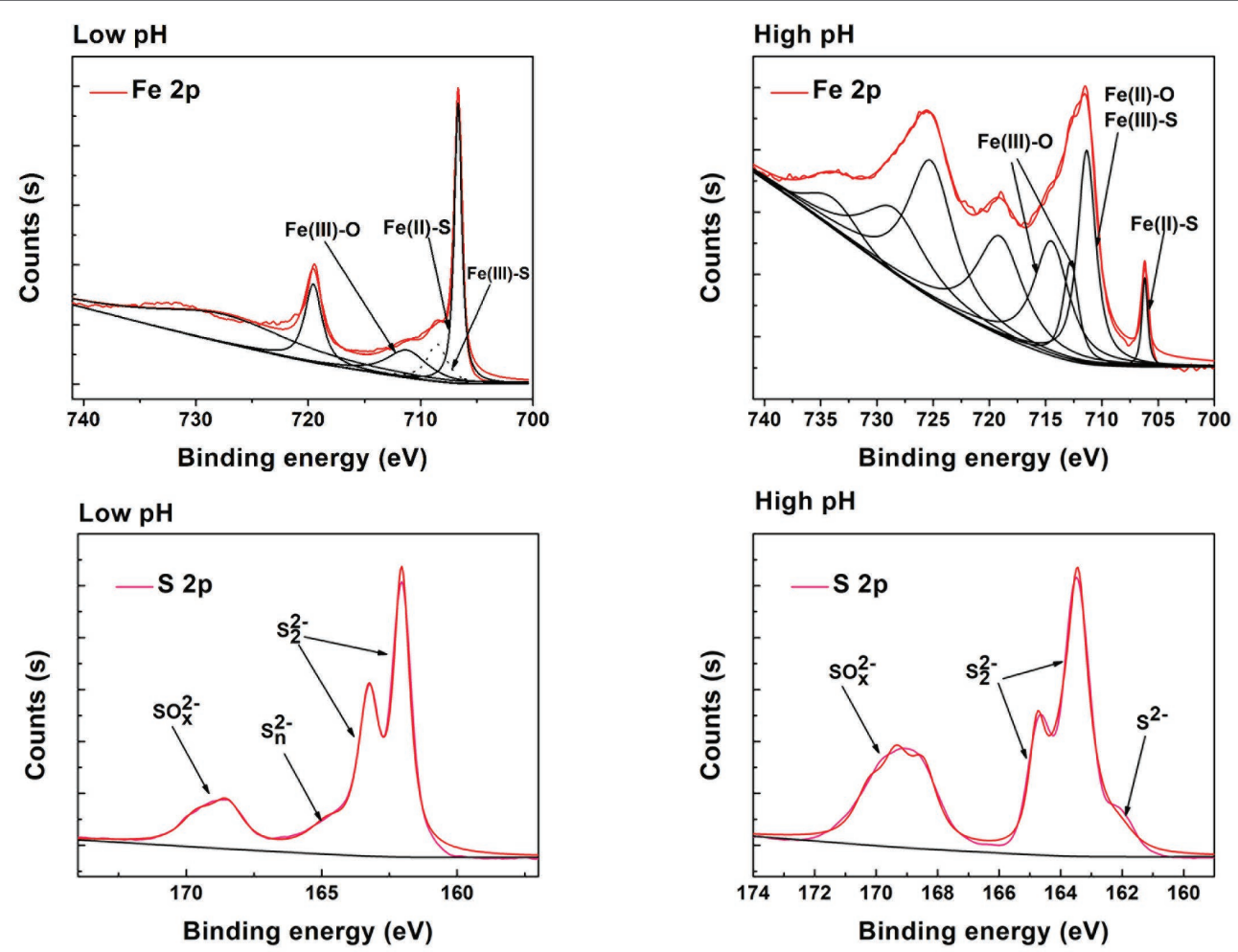

High pH

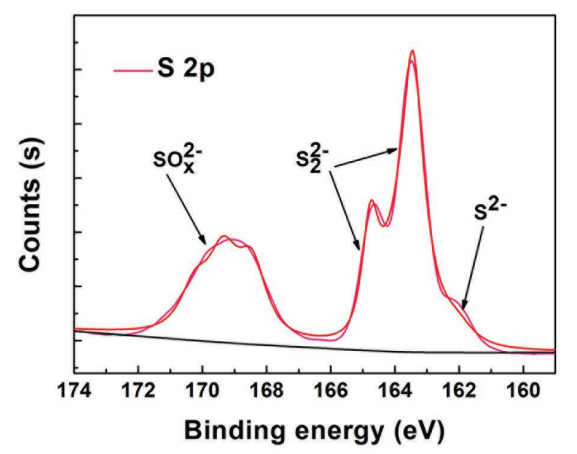

FIGURE 9 | Fitted XPS core level spectra of the S, Fe from different pH environments.

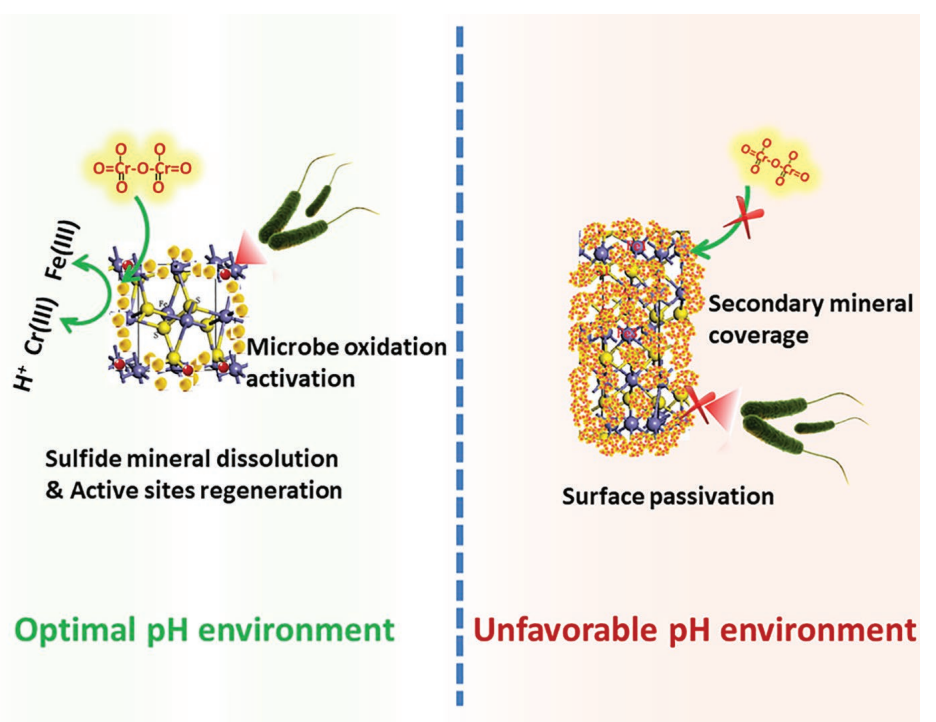

FIGURE 10 | Schematic of $\mathrm{Cr}(\mathrm{VI})$ reduction in different $\mathrm{pH}$ environments. 
environments than that in low-pH systems. The XPS results were in good agreement with those of the other tests. Both the secondary iron minerals and the elemental sulfur formation would inhibit pyrite dissolution, yet the activity of acidophilic bacteria efficiently promoted pyrite dissolution, resulting in proton and reactive site regeneration in $\mathrm{Cr}(\mathrm{VI})$ reduction. These biological activities depended on an appropriate physiological $\mathrm{pH}$. The synergistic effect between pyrite and A. ferrooxidans can only be achieved in the optimal $\mathrm{pH}$ range. Figure 10 summarizes the $\mathrm{Cr}(\mathrm{VI})$ reduction mechanisms in different $\mathrm{pH}$ environments.

\section{CONCLUSIONS}

In this study, the influence of $\mathrm{pH}$ and dosage on pyrite-based $\mathrm{Cr}(\mathrm{VI})$ reduction efficiency was systematically investigated. The results showed that pyrite based $\mathrm{Cr}(\mathrm{VI})$ reduction was a highly proton-dependent process. The $\mathrm{Cr}(\mathrm{VI})$ reduction capacity of both $\mathrm{BI}$ and $\mathrm{CI}$ systems decreased with increasing $\mathrm{pH}$. However, the activity of $A$. ferrooxidans significantly enhanced the $\mathrm{Cr}(\mathrm{VI})$ removal efficiency. With increasing $\mathrm{pH}$, the reduction efficiency of $\mathrm{pH}$-stable biological systems was improved by 4.2, 19.4, 14.7, 72.3, 68.1, and 94.3\% compared with under $\mathrm{pH}$-stable chemical treatment. The highest reduction efficiency of the biological system was achieved in a specific $\mathrm{pH}$ range. Pyrite dissolution and reactive site regeneration were promoted by A. ferrooxidans, which resulted in the enhancement of $\mathrm{Cr}(\mathrm{VI})$ reduction. The complexity of the pyrite-based reduction system increased due to interaction between bacteria and pyrite, resulting in the decrease in the linear relevancy between $\mathrm{pH}$ and $\mathrm{Cr}(\mathrm{VI})$ dosage. The passivation effect became more significant with increasing $\mathrm{pH}$, and secondary iron mineral formation will have inhibited the pyrite dissolution. However, the inhibition effect was relieved under the activity of $A$. ferrooxidans due to $\mathrm{S} / \mathrm{Fe}$ oxidization. A balance between $\mathrm{Cr}(\mathrm{VI})$ reduction and

\section{REFERENCES}

Bae, S., and Hanna, K. (2015). Reactivity of nanoscale zero-valent iron in unbuffered systems: effect of $\mathrm{pH}$ and $\mathrm{Fe}$ (II) dissolution. Environ. Sci. Technol. 49, 10536-10543. doi: 10.1021/acs.est.5b01298

Christel, S., Herold, M., Bellenberg, S., Buetti-Dinh, A., El Hajjami, M., Pivkin, I. V., et al. (2018). Weak iron oxidation by Sulfobacillus thermosulfidooxidans maintains a favorable redox potential for chalcopyrite bioleaching. Front. Microbiol. 9:3059. doi: 10.3389/fmicb.2018.03059

Cordoba, E. M., Munoz, J. A., Blazquez, M. L., Gonzalez, F., and Ballester, A. (2009). Passivation of chalcopyrite during its chemical leaching with ferric ion at $68^{\circ}$ C. Miner. Eng. 22, 229-235. doi: 10.1016/j.mineng.2008.07.004

Demoisson, F., Mullet, M., and Humbert, B. (2005). Pyrite oxidation by hexavalent chromium: investigation of the chemical processes by monitoring of aqueous metal species. Environ. Sci. Technol. 39, 8747-8752. doi: 10.1021/es050717s

Demoisson, F., Mullet, M., and Humbert, B. (2007). Investigation of pyrite oxidation by hexavalent chromium: solution species and surface chemistry. J. Colloid Interface Sci. 316, 531-540. doi: 10.1016/j.jcis.2007.08.011

Doyle, C. S., Kendelewicz, T., Bostick, B. C., and Brown, G. E. (2004). Soft $\mathrm{X}$-ray spectroscopic studies of the reaction of fractured pyrite surfaces with Cr(VI)-containing aqueous solutions. Geochim. Cosmochim. Acta 68, 4287-4299. doi: $10.1016 /$ j.gca.2004.02.015 biological activity was critical for a sustainable reduction reaction. This research was an extension of the biohydrometallurgy technique in the environmental remediation area.

\section{DATA AVAILABILITY STATEMENT}

The raw data supporting the conclusions of this manuscript will be made available by the authors, without undue reservation, to any qualified researcher.

\section{AUTHOR CONTRIBUTIONS}

MG conceptualized the study and wrote the manuscript. XL and HW carried the experiment. GQ helped in revising the manuscript.

\section{FUNDING}

We gratefully acknowledge the financial support of the National Natural Science Foundation of China (51804350 and 41773089), the Natural Science Foundation of Hunan Province, China (2019JJ50769), the postdoctoral grants for MG from the Chinese PD Science Foundation (2017M610506, 2018T110842, 185690), the Shanghai Tongji Gao Tingyao Environment Protection Science and Technology Development Foundation, and the Open Sharing Fund for the Large-scale Instruments and Equipment of Central South University (CSUZC201909).

\section{SUPPLEMENTARY MATERIAL}

The Supplementary Material for this article can be found online at: https://www.frontiersin.org/articles/10.3389/fmicb.2019.03082/ full\#supplementary-material

Gan, M., Li, J., Sun, S., Cao, Y., Zheng, Z., Zhu, J., et al. (2018). The enhanced effect of Acidithiobacillus ferrooxidans on pyrite based $\mathrm{Cr}(\mathrm{VI})$ reduction. Chem. Eng. J. 341, 27-36. doi: 10.1016/j.cej.2018.02.014

Gan, M., Sun, S. J., Zheng, Z. H., Tang, H. J., Sheng, J. R., Zhu, J. Y., et al. (2015). Adsorption of $\mathrm{Cr}(\mathrm{VI})$ and $\mathrm{Cu}(\mathrm{II})$ by AlPO4 modified biosynthetic Schwertmannite. Appl. Surf. Sci. 356, 986-997. doi: 10.1016/j.apsusc. 2015.08.200

Gong, Y., Gai, L., Tang, J., Fu, J., Wang, Q., and Zeng, E. Y. (2017). Reduction of $\mathrm{Cr}(\mathrm{VI})$ in simulated groundwater by FeS-coated iron magnetic nanoparticles. Sci. Total Environ. 595, 743-751. doi: 10.1016/j.scitotenv.2017.03.282

Harvey, A. E. Jr., Smart, J. A., and Amis, E. S. (1955). Simultaneous spectrophotometric determination of iron (II) and total iron with 1, 10-phenanthroline. Anal. Cheml. 27, 26-29.

He, Y. T., and Traina, S. J. (2005). Cr(VI) reduction and immobilization by magnetite under alkaline $\mathrm{pH}$ conditions: the role of passivation. Environ. Sci. Technol. 39, 4499-4504. doi: 10.1021/es0483692

Huggins, F. E., Rezaee, M., Honaker, R. Q., and Hower, J. C. (2016). On the removal of hexavalent chromium from a class F fly ash. Waste Manag. 51, 105-110. doi: 10.1016/j.wasman.2016.02.038

Jiang, B., Liu, Y., Zheng, J., Tan, M., Wang, Z., and Wu, M. (2015). Synergetic transformations of multiple pollutants driven by $\mathrm{Cr}(\mathrm{VI})$-sulfite reactions. Environ. Sci. Technol. 49, 12363-12371. doi: 10.1021/acs.est.5b03275 
Kantar, C., Ari, C., and Keskin, S. (2015). Comparison of different chelating agents to enhance reductive $\mathrm{Cr}(\mathrm{VI})$ removal by pyrite treatment procedure. Water Res. 76, 66-75. doi: 10.1016/j.watres.2015.02.058

Kantar, C., and Bulbul, M. S. (2016). Effect of pH-buffering on Cr(VI) reduction with pyrite in the presence of various organic acids: continuous-flow experiments. Chem. Eng. J. 287, 173-180. doi: 10.1016/j.cej.2015.11.019

Kim, S. D., Park, K. S., and Gu, M. B. (2002). Toxicity of hexavalent chromium to Daphnia magna: influence of reduction reaction by ferrous iron. J. Hazard. Mater. 93, 155-164. doi: 10.1016/S0304-3894(02)00057-2

Kim, C., Zhou, Q. H., Deng, B. L., Thornton, E. C., and Xu, H. F. (2001). Chromium(VI) reduction by hydrogen sulfide in aqueous media: stoichiometry and kinetics. Environ. Sci. Technol. 35, 2219-2225. doi: 10.1021/es0017007

Lara, R. H., Vazquez-Arenas, J., Ramos-Sanchez, G., Galvan, M., and Lartundo-Rojas, L. (2015). Experimental and theoretical analysis accounting for differences of pyrite and chalcopyrite oxidative behaviors for prospective environmental and bioleaching applications. J. Phys. Chem. C 119, 18364-18379. doi: $10.1021 /$ acs.jpcc.5b05149

Li, Y. Y., Liang, J. L., He, X., Zhang, L., and Liu, Y. S. (2016). Kinetics and mechanisms of amorphous FeS2 induced $\mathrm{Cr}(\mathrm{VI})$ reduction. J. Hazard. Mater. 320, 216-225. doi: 10.1016/j.jhazmat.2016.08.010

Lin, Y.-T., and Huang, C.-P. (2008). Reduction of chromium(VI) by pyrite in dilute aqueous solutions. Sep. Purif. Technol. 63, 191-199. doi: 10.1016/j. seppur.2008.05.001

Mandal, S., Sarkar, B., Bolan, N., Ok, Y. S., and Naidu, R. (2017). Enhancement of chromate reduction in soils by surface modified biochar. J. Environ. Manag. 186, 277-284. doi: 10.1016/j.jenvman.2016.05.034

Meruane, G., and Vargas, T. (2003). Bacterial oxidation of ferrous iron by Acidithiobacillus ferrooxidans in the $\mathrm{pH}$ range 2.5-7.0. Hydrometallurgy 71, 149-158. doi: 10.1016/S0304-386X(03)00151-8

Mielke, R. E., Pace, D. L., Porter, T., and Southam, G. (2003). A critical stage in the formation of acid mine drainage: colonization of pyrite by Acidithiobacillus ferrooxidans under $\mathrm{pH}$-neutral conditions. Geobiology 1, 81-90. doi: 10.1046/j. 1472-4669.2003.00005.x

Mullet, M., Demoisson, F., Humbert, B., Michot, L. J., and Vantelon, D. (2007). Aqueous $\mathrm{Cr}(\mathrm{VI})$ reduction by pyrite: speciation and characterisation of the solid phases by X-ray photoelectron, Raman and X-ray absorption spectroscopies. Geochim. Cosmochim. Acta 71, 3257-3271. doi: 10.1016/j.gca.2006.09.008

Olson, G. J., Brierley, J. A., and Brierley, C. L. (2003). Bioleaching review part B: progress in bioleaching: applications of microbial processes by the minerals industries. Appl. Microbiol. Biotechnol. 63, 249-257. doi: 10.1007/ s00253-003-1404-6
Parker, D. L., Borer, P., and Bernier-Latmani, R. (2011). The response of Shewanella oneidensis MR-1 to $\mathrm{Cr}(\mathrm{III})$ toxicity differs from that to $\mathrm{Cr}(\mathrm{VI})$. Front. Microbiol. 2:223. doi: 10.3389/fmicb.2011.00223

QuiIntana, M., Curutchet, G., and Donati, E. (2001). Factors affecting chromium (VI) reduction by Thiobacillus ferrooxidans. Biochem. Eng. J. 9, 11-15. doi: 10.1016/S1369-703X(01)00116-4

Schippers, A., Jozsa, P., and Sand, W. (1996). Sulfur chemistry in bacterial leaching of pyrite. Appl. Environ. Microbiol. 62, 3424-3431. doi: 10.1128/ AEM.62.9.3424-3431.1996

Stott, M. B., Watling, H. R., Franzmann, P. D., and Sutton, D. (2000). The role of iron-hydroxy precipitates in the passivation of chalcopyrite during bioleaching. Miner. Eng. 13, 1117-1127. doi: 10.1016/S0892-6875(00)00095-9

Sun, H. Y., Chen, M., Zou, L. C., Shu, R. B., and Ruan, R. M. (2015). Study of the kinetics of pyrite oxidation under controlled redox potential. Hydrometallurgy 155, 13-19. doi: 10.1016/j.hydromet.2015.04.003

Tu, Z., Guo, C., Zhang, T., Lu, G., Wan, J., Liao, C., et al. (2017). Investigation of intermediate sulfur species during pyrite oxidation in the presence and absence of Acidithiobacillus ferrooxidans. Hydrometallurgy 167, 58-65. doi: 10.1016/j.hydromet.2016.11.001

Wang, R., Lin, J. Q., Liu, X. M., Pang, X., Zhang, C. J., Yang, C. L., et al. (2019). Sulfur oxidation in the acidophilic autotrophic Acidithiobacillus spp. Front. Microbiol. 9:3290. doi: 10.3389/fmicb.2018.03290

Zhu, J. Y., Gan, M., Zhang, D., Hu, Y. H., and Chai, L. Y. (2013). The nature of Schwertmannite and Jarosite mediated by two strains of Acidithiobacillus ferrooxidans with different ferrous oxidation ability. Mater. Sci. Eng. C 33, 2679-2685. doi: 10.1016/j.msec.2013.02.026

Zhu, J. Y., Wang, Q. F., Zhou, S., Li, Q., Gan, M., Jiang, H., et al. (2015). Insights into the relation between adhesion force and chalcopyrite-bioleaching by Acidithiobacillus ferrooxidans. Colloids Surf. B 126, 351-357. doi: 10.1016/j. colsurfb.2014.11.036

Conflict of Interest: The authors declare that the research was conducted in the absence of any commercial or financial relationships that could be construed as a potential conflict of interest.

Copyright (C) $2020 \mathrm{Liu}, \mathrm{Wu}, \mathrm{Gan}$ and Qiu. This is an open-access article distributed under the terms of the Creative Commons Attribution License (CC BY). The use, distribution or reproduction in other forums is permitted, provided the original author(s) and the copyright owner(s) are credited and that the original publication in this journal is cited, in accordance with accepted academic practice. No use, distribution or reproduction is permitted which does not comply with these terms. 